\title{
Gender Identities in Women's and Feminist Periodicals in Serbia
}

\author{
Review essay by Ana Kolarić
}

Slobodanka Peković, Časopisi po meri dostojanstvenog ženskinja: Ženski časopisi na početku 20. veka (Journals suited for respectable women: Women's journals from the early twentieth century), Novi Sad-Beograd: Matica srpska, Institut za književnost i umetnost, 2015, 378 pp., RSD 550 (paperback), ISBN 978-86-7946-154-4.

Stanislava Barać, Feministička kontrajavnost: Žanr ženskog portreta u srpskoj periodici 19201941 (The feminist counterpublic: A genre of woman's portrait in the Serbian periodical press from 1920 to 1941), Beograd: Institut za književnost i umetnost, 2015, 436 pp., RSD 1100 (paperback), ISBN 978-86-7095-224-9.

Since the 1990s, feminist periodical studies have flourished in Anglo-American scholarship, especially among researchers and academics who are interested in exploring modernity and modernism. ${ }^{1}$ They usually examine the work of many unknown, forgotten, or marginalized women authors (writers, journalists, editors) and, more often than not, their research challenges the dominant view of literary and cultural history, highlighting not only that each tradition or history is selective and exclusive, but also that it is always marked by various power relations. Furthermore, feminist periodical studies analyze the link between categories of gender and modernity in rather new ways. The two books under review here are examples of such research in Serbian scholarship. ${ }^{2}$ Časopisi po meri dostojanstvenog ženskinja: Ženski časopisi na početku 20. veka (Journals suited for respectable women: Women's journals from the early twentieth century), by Slobodanka Peković, examines a number of women's journals in Serbia in the late nineteenth and the first half of the twentieth century, focusing on the structure of women's periodicals as a specific genre and on emancipatory ideas, although sometimes contradictory and ambivalent, which were produced in, and spread by, those journals. In contrast to Peković, who examines journals from the turn of the century, Stanislava Barać focuses exclusively on the interwar period in her book, Feministička kontrajavnost: Žanr ženskog portreta u srpskoj periodici 1920-1941 (The feminist counterpublic: A genre of 
woman's portrait in the Serbian periodical press from 1920 to 1941). Since the historical, political, and cultural contexts substantially changed in the latter period, there is one significant novelty in Barać's research: she studies explicitly feminist journals. This shift from women's and some feminist journals to the specifically feminist press indicates the main distinction between the two studies, which is evident in Pekovićs and Baraćs research sample, as well as in their theoretical and methodological choices.

The feminist periodical press has been studied in Serbia in two places: for several decades already at the Institute of Literature and Arts in Belgrade, as a part of the institute's broader project in periodical studies; ${ }^{3}$ and within the framework of the research project "Knjiženstvo- Theory and History of Women's Writing in Serbian until 1915," which started at the Faculty of Philology, University of Belgrade, in 2011. ${ }^{4}$ Research in Serbia must also be understood in relation to international feminist studies on the periodical press, which first appeared in connection to Victorian periodicals, ${ }^{5}$ and later expanded as an important avenue of research in the feminist revision of modernism. ${ }^{6}$ Barbara Green, for example, believes that the women's/feminist periodical press is important for researchers who work on gender and modern literary cultures, not only because these periodicals publish unknown or less well-known authors, but because they often provide a more complex and nuanced image of the cultures of modernity. ${ }^{7}$ Furthermore, Green identifies three important theoretical areas of research in the feminist periodical press: "descriptions of the workings of the feminist public sphere"; "the relationship between feminism and the varied literary and cultural movements of modernity"; and "the study of experience of modernity." 8

As one of the pioneers in the field of women's and feminist periodical press studies in Yugoslavia/Serbia, ${ }^{9}$ Slobodanka Peković has managed to successfully encompass all three aforementioned theoretical areas of research throughout her long and fruitful career. In her latest book, Časopisi po meri dostojanstvenog ženskinja, dedicated to women's and feminist periodicals in Serbia mainly from the early twentieth century, such as Domaćica (The housewife), Žena (The woman), and Ženski pokret (The women's movement), Peković asks the apparently simple question of what it means to be a woman. Her book represents a synthesis of valuable insights and conclusions that stem from her long work on the topic. Peković focuses on two crucial aspects of every journal: structure (an analysis of the magazine's various and often unchanging columns) and content (an analysis of the main topics and problems). This is indicated in the titles and subtitles of the book: she analyzes different columns (dedicated to political and social issues, literature, literary criticism, etc.), editorials, illustrations, notes, correspondence, and advertisements, as well as topics including education, morality, gender stereotypes, feminism and emancipation, nationalism, and patriotism. As in her other works, Peković notes a difference between two distinct types of women's journals: those established and edited by women and aimed at women, and those meant for women, but created by men. ${ }^{10}$

Women's magazines, according to Peković, represented "an important part of popular culture and had an unexpected political and social subversive effect." 11 Their editors and authors discussed and criticized the typical position of women and existing gender relations within Serbian patriarchal society. Despite the alignment between many women's magazines from the early twentieth century and patriarchy-align- 
ment that was in tune with nation-building processes of that time-these magazines strived to foster transformations of Serbian society that would benefit women. These magazines constructed woman's identity in accordance with specific (ideal) character traits and moral values, as well as in relation to the particular tasks and capacities prescribed for women (nurturing and caring, in the first place), as noticed by Peković. The analysis of such identities presupposes an understanding of the historical, social, political, and cultural contexts in which women's magazines emerged and in which they were published, as these particular contexts had largely shaped specific conceptions of "proper" morality and gender roles. ${ }^{12}$

Slobodanka Peković identifies four important topics central to every women's magazine from the early twentieth century that she explored: education, enlightenment, feminism, and nationalism. She sees these topics as connecting the dots between the public sphere (Jürgen Habermas) ${ }^{13}$ and women's/feminist counterpublic sphere or subaltern counterpublics (Nancy Fraser): ${ }^{14}$ every examination of (gender-based) injustice and inequality in women's and feminist counterpublic spheres is, in fact, aimed at changing and transforming dominant values and patterns of behavior produced in and maintained by the public sphere, from debates on education and professions for women to those about marriage and divorce.

Peković demonstrates that the enlightenment project was intrinsically connected to the idea of patriotic motherhood according to which women should get the right to education in order to become better mothers, wives, and housewives. Thus, women's education was not seen as a potentially dangerous tool that could easily trigger a more substantial change in a society, but as a necessary element in creating a strong national state and identity. Peković notices that women's magazines acknowledged the dual nature of education: "According to women's magazines, education takes place in the courses and lectures organized by schools and societies, but it also happens through reading, individually." ${ }^{15}$ Editors of women's and feminist periodicals created a safe space in which women learned how to discuss and debate important-and sometimes taboo-subjects, and, consequently, how to take part in public discussions and demand their rights. ${ }^{16}$ Peković rightly believes that women's periodicals from the early twentieth century represented "the bridge between culture and subculture created by women excluded from the public sphere."17

Stanislava Barać's comprehensive study Feministička kontrajavnost is a result of her doctoral research on the feminist and feminophile press in interwar Serbia, at that time part of the Kingdom of Serbs, Croats, and Slovenians/Yugoslavia (1918-1941). The structure of the book indicates its wide-ranging scope, especially with regard to the research sample. Besides chapters in which Barać explains her theory and method and analyzes nine different journals, this book also contains a selective bibliography of women's portraits as well as an appendix. In the first four chapters, Barać explains the theoretical and methodological framework of the study. Barać, who is theoretically very well-informed, draws her conclusions mainly from Anglo-American feminist theory and criticism (gynocriticism, feminist media studies, feminist history, scholarship on women's literature), cultural studies, and periodical studies. However, Barać also identifies and coins a new genre that she calls woman's portrait. In this sense, she works on the production of local knowledge. 
The first chapter explains what the woman's portrait genre is: the phrase stands for "a specific genre in the periodical press in a concrete historical period and cultural milieu"; or, as her research shows, this genre is typical of the feminist and feminophile periodical press in the interwar period in Serbia/Yugoslavia. ${ }^{18}$ Barać points out that her definition of a woman's portrait is grounded in three related but distinct research and theoretical fields: the exploration of women's genres in popular culture and mass media; theorizations and conceptualizations of different relations between categories of gender and genre in literature; and finally, gynocritical research. ${ }^{19}$ In a nutshell, articles that the author categorizes as women's portraits (reviews, essays, longer studies, poems, and short stories published in periodicals) were written by women about women, including both predecessors and contemporary women, from a feminist standpoint and with emancipatory goals. Barać's undeniable flare for theoretical precision is most obvious when she explains the distinction between a woman's portrait and the portrait of a woman: the former is inherently feminist and emancipatory, fostering concrete political goals, whereas the latter does not necessarily have to be like that. In other words, the woman's portrait genre is determined mainly by its content, while other distinctions are less important (e.g., the woman's portrait genre can be exemplified by either a poem, or an essay, or a short story).

The second important theoretical concept in Baraćs book is the feminist counterpublic, which first appears in its most visible and indicative manner in the title of the book. At the outset, Barać provides an informative literature review, starting with Jürgen Habermas's definition of the public sphere and extending to many feminist interpretations and revisions of his concept of the bourgeois (liberal) public sphere. She relies on the ideas developed by Nancy Fraser: subaltern counterpublics have always existed together with, and in opposition to, the hegemonic public sphere. In the Yugoslav/Serbian context, the concept of the feminist counterpublic encompasses different periodicals and feminist movements from that period, such as the radical bourgeois movement, the moderate movement, and the socialist movement. In other words, Barać believes, and successfully demonstrates, that feminism covered various tendencies: from those dealing with problems of highly educated women to those paying attention to the everyday lives of female workers. Barać's research shows that this feminist counterpublic was not homogeneous or uniform: each periodical had its own editorial politics, mission, goals, and, consequently, its own reading audience.

The third concept connects all women's portraits presented and analyzed in the book, and involves the ideologeme of the New Woman. The New Woman is highly educated, employed, and independent, or, simply put, the ideal of women's emancipation at that time. Of course, utilizations and perceptions of this ideologeme varied from magazine to magazine, depending on its central mission.

Barać examines both the women's portrait texts and the contexts in which they appeared using critical discourse analysis. This method, which is based largely on linguistics and critical theory and focused on concepts of power, discourse, exclusion, hegemony, and representation, provides researchers with an apparatus for the careful analysis of implicit and explicit textual meanings, that is, the examination of assumptions and presuppositions within the texts. Ideological effects of texts are particularly visible when analyzing the assumptions in them. The process of meaning making de- 
pends on not only what is explicit in a text, but what is implicit as well. ${ }^{20}$ As mentioned by Norman Fairclough, the role of assumptions is crucial: "what is 'said' in a text is always said against the background of what is 'unsaid,' but taken as given." 21 If texts do ideological work by taking some claims as unquestioned and inevitable reality, as Fairclough claims, then this ideological work might be seen as an attempt to universalize particular meanings to achieve and keep dominance. However, the struggle for hegemony presumes more than just one participant. Therefore, there is no single discourse; there are competing discourses utilized by groups of people in different social positions. $^{22}$

Barać's analysis of the concrete journals - feminophile journals such as Nova Evropa (New Europe) and Misao (Thought); feminist and socialist journals and newspapers such as Ženski pokret (The women's movement), Jednakost (Equality), Jugoslovenska žena (The Yugoslav woman), and Žena danas (Woman today); and feminist-oriented illustrated magazines such as Žena $i$ svet (Woman and the world) and Ženski svet (Women's world) - shows that the feminist counterpublic was diverse and heterogeneous, while emancipatory discourses were sometimes contradictory. For example, becoming a "New Woman," or an emancipated woman, in socialist journals was just a means to an end - to becoming a socialist, revolutionary woman. The fight against class inequality and social injustice was more important and universal than the struggle for women's equal rights (it was expected that "the woman question" would be automatically solved in a socialist political regime).

After her analysis of the aforementioned journals, Barać examines two particularly interesting issues. First she explores the magazine Seljanka (Rural woman) (1933-1935) as an example of folk enlightenment - there was no fostering of women's emancipation in it. Within this periodical, she analyzes women's anti-portraits and, more broadly, the position of rural women in that period and their detachment from the feminist counterpublic. Needless to say, the number of often illiterate rural women was much larger than the number of "New Women." Barać's analysis proves to be both comprehensive and nuanced: instead of glorifying and even romanticizing the feminist counterpublic in Serbia in the interwar period (although women's organizations and feminist movements that comprised this counterpublic were, without any doubt, significant and life-changing for some women), she extends her research to a magazine such as Seljanka to show that modernization processes, especially relating to women and their emancipation, take a very long time.

Barać makes yet another contribution in this meticulous study: in her last chapter she employs definitions and theorizations of the women's portrait genre and the New Woman to identify fiction that speaks about these phenomena-the literature of the "New Woman." She offers several analyses of such fiction, but mostly suggests that this kind of literature might represent an interesting and rich new research field in literary studies in Serbia.

In conclusion, not only do the reviewed books by Slobodanka Peković and Stanislava Barać provide readers with an insightful analysis of the women's and feminist periodical press in Serbia from the late nineteenth and the first half of the twentieth century, but they also offer a comprehensive bibliography of relevant scholarly articles and books on this subject and indicate new, nuanced readings and interpretations of 
Serbian literary and cultural history. These books will be useful to scholars involved in women's and periodical studies in the Serbian language (in both Serbia and in other countries in the region) and to scholars working in departments of Slavic languages and literatures or Central and Southeast European studies.

\section{$\diamond$ About the Author}

Ana Kolarić is an Assistant Professor at the Department of Comparative Literature and Literary Theory, Faculty of Philology, University of Belgrade. She graduated from the Department of Comparative Literature and Literary Theory, and obtained her joint master's degree in women's and gender studies in Europe from the Department of Gender Studies, Central European University, Budapest, and the General Graduate Gender Programme, Faculty of Humanities, Utrecht University. In 2015, she defended her PhD dissertation in the field of modern and feminist periodical studies at the Faculty of Philology, University of Belgrade. Since 2011, she has been working on the research project "Knjiženstvo-Theory and History of Women's Writing in Serbian until 1915." She has published a book, Rod, modernost i emancipacija: Uredničke politike u časopisima Žena (1911-1914) i The Freewoman (1911-1912) (Gender, modernity, and emancipation: Politics of editing in journals "The woman" [1911-1914] and "The Freewoman" [1911-1912]) (Belgrade: Fabrika knjiga, 2017), and coedited (with Biljana Dojčinović) a collection of essays, Feministička štampa u Srbiji: Teorija, aktivizam $i$ umetničke prakse u 1990-im i 2000-im (The feminist press in Serbia: Theory, activism, and art practices in the 1990s and 2000s) (2018). Her research interests include feminist theory and criticism, cultural studies, modern and feminist periodical studies, women's history, and women and education. E-mail: ana.kolaric16@gmail.com

\section{$\diamond$ Notes}

1. See, for example, Rita Felsi, The Gender of Modernity (Cambridge, MA: Harvard University Press, 1995); Bonnie Kime Scott, ed., Gender in Modernism: New Geographies, Complex Intersections (Urbana: University of Illinois Press, 2007); Ann Ardis and Leslie W. Lewis, eds., Women's Experience of Modernity, 1875-1945 (Baltimore: The Johns Hopkins University Press, 2003); Ann Ardis and Patrick Collier, eds., Transatlantic Print Culture, 1880-1940: Emerging Media, Emerging Modernisms (New York: Palgrave Macmillan, 2008); Lucy Delap, The Feminist Avant-Garde: Transatlantic Encounters of the Early Twentieth Century (Cambridge: Cambridge University Press, 2007); Maria DiCenzo, Lucy Delap, and Leila Ryan, Feminist Media History: Suffrage, Periodicals and the Public Sphere (New York: Palgrave Macmillan, 2011); Jayne Marek, Women Editing Modernism: "Little" Magazines \& Literary History (Lexington: University of Kentucky Press, 1995); Mark Morrisson, The Public Face of Modernism: Little Magazines, Audiences, and Reception, 19051920 (Madison: University of Wisconsin Press, 2001); Robert Scholes and Clifford Wulfman, Modernism in the Magazines: An Introduction (New Haven, CT: Yale University Press, 2010).

2. In 2015, I defended a doctoral thesis dealing with two women's/feminist journals and afterward published a book based on it: Rod, modernost i emancipacija: Uredničke politike u časopisima Žena (1911-1914) $i$ The Freewoman (1911-1912) [Gender, modernity, and emancipation: Politics of editing in journals "The woman" (1911-1914) and "The Freewoman" (1911-1912)] (Belgrade: Fabrika knjiga, 2017). In 2016, Jelena Milinković defended her doctoral thesis on women's writ- 
ings in feminophile journals: “Ženska književnost u časopisu Misao (1919-1937)” [Woman's literature in journal thought (1919-1937)] (PhD diss., University of Belgrade, 2016).

3. For information about the periodical studies research project at the Institute for Literature and Arts, see http://www.ikum.org.rs/pages.php?page=projekti_periodika (accessed 30 November 2018).

4. For information about the research project as well as the journal Knjiženstvo [Journal for studies in literature, gender, and culture], see http://www.knjizenstvo.rs/?lang=en (accessed 30 November 2018).

5. See, e.g., Hilary Fraser, Stephanie Green, and Judith Johnston, eds., Gender and the Victorian Periodical (Cambridge: Cambridge University Press, 2003); and Jennifer Phegley, Educating the Proper Woman Reader: Victorian Family Literary Magazines and the Cultural Health of the Nation (Columbus: The Ohio State University Press, 2004).

6. See, e.g., Aleta Feinsod Cane and Susan Alves, eds., "The Only Efficient Instrument": American Women Writers and the Periodical, 1837-1916 (Iowa City: University of Iowa Press, 2001); Bonnie Kime Scott, ed., Gender in Modernism: New Geographies, Complex Intersections (Urbana: University of Illinois Press, 2007); Marek, Women Editing Modernism.

7. Barbara Green, "The Feminist Periodical Press: Women, Periodical Studies, and Modernity," Literature Compass 6, no. 1 (2009): 191-205, here 192.

8. Ibid., 193.

9. The interview with Slobodanka Peković, conducted by Ana Kolarić and Stanislava Barać, has been published in Serbian and English as well, in Knjiženstvo, no. 6 (2016), http://www.knji zenstvo.rs/magazine.php?text=176 (accessed 30 November 2018).

10. Peković, Časopisi po meri dostojanstvenog ženskinja, 26.

11. Ibid., 13.

12. Ibid., 22.

13. Jürgen Habermas, Sara Lennox, and Frank Lennox, "The Public Sphere: An Encyclopedia Article (1964)," in New German Critique, no. 3 (Autumn 1974): 49-55.

14. Nancy Fraser, "Rethinking the Public Sphere: A Contribution to the Critique of Actually Existing Democracy," Social Text, nos. 25-26 (1990): 56-80.

15. Peković, Časopisi po meri dostojanstvenog ženskinja, 197.

16. Ibid., 204-205.

17. Ibid., 206.

18. Barać, Feministička kontrajavnost, 11.

19. Ibid., 333.

20. Norman Fairclough, Analysing Discourse: Textual Analysis for Social Research (London: Routledge, 2003), 11.

21. Ibid., 40.

22. Ibid., 17. 